\title{
Expression of glial acidic fibrillary protein delta and E-cadherin in ependymomas; clinic-pathological and immunohistochemistry correlation
}

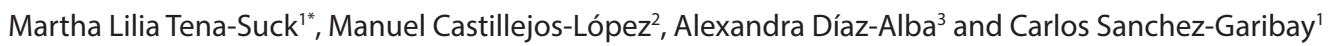

*Correspondence: mltenasuck@gmail.com

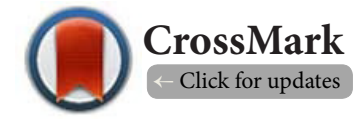

'Department of Neuropathology, National Institute of Neurology and Neurosurgery, "Manuel Velasco Suárez", Av Insurgentes 2Sur 3877 Col. La Joya, Delegación Tlalpan CP 14269, México.

${ }^{2}$ Service of epidemiology (Epidemiological Survillance Service). National Institute of Respiratory disease (INER). México city México, Calzada de Tlalpan 4502, colonia sección XVI. Delegación Tlalpan cp. 14080, México.

${ }^{3}$ Resident of Neurology. National Institute of Neurology and Neurosurgery, "Manuel Velasco Suárez", Av Insurgentes Sur 3877 Col. La Joya, Delegación Tlalpan CP 14269, México.

\begin{abstract}
Background: Ependymoma is a tumor that formed from the ependyma. Usually, in paediatric cases the location is intracranial, while in adults it is spinal.

Methods: We study the prognostic implications of the current grading system, of histological and immunohistochemical features of GFAP, GFAP- $\delta$, EMA, neurofilament and E-cadherin expression and Ki-67 in ependymomas.

Results: 60 cases were included in this study of which 32 were female and 28 were male, aging ranged from 18 to 65 years old (mean age of $34.18 \pm 11.35 \mathrm{yr}$ ). 17 were supratentorial, 25 infratentorial and 18 cases were spinal location. Histologically 15 were grade 1, 36 were grade II and 9 grade III. 23 cases recurrence (4, 13 and 6 stage III respectively), with mean age 34.52 12.23 years vs $33.97 \pm 97.94$ that not recurrence. The expression of GFAP- $\delta$ was negative in 38 cases and positive in $21(p=0.359)$. GFAP- $\delta$ expression was correlated with anaplastic type (grade III). Tumor grade and tumor size, brain invasion, atypia, and mitosis features and also were correlated with higher expression of neurofilament, higher ki67-Li, as well as loss of immnunoexpression of E-Cadherina and EMA.

Conclusions: PGAF, S-100, and GFAP- $\delta$ expression in ependymomas varied and depends of the histologic grade likewise the value of proliferation index. The expression of GFAP- $\delta$ was in directly relationship with presence of neurofilament and loss of E-Cadherins and EMA expression. Studies have suggested that human ependimomas arise from regionally distinct populations of radial glial cells.
\end{abstract}

Keywords: E-cadherin, ependymoma, immunohistochemistry, GFAP- $\delta$, Ki-67

\section{Introduction}

Ependymoma is a brain tumour that may be located in the supratentorial, infratentorial or posterior fossa as well as spinal cord [1], affects the walls of the ventricles [1-3]. Ependymoma is usually considered non-infiltrative tumor [3-8]. The location of the tumor is an important factor for prognosis $[8,9]$.

The histologic variants of ependymoma are classified according to the World Health Organization (WHO) grading system [1]. Classical WHO, grade I including; Myxopapillary ependymoma (MPE) that occur in the phylum terminalis of the spinal cord, grade II ependymoma (include cellular, papillary, tanacytic, giant cell, epithelioid, and clear cell variants) and grade III corresponding the anaplastic ependymoma subtype [1]. Different histological or immunohistochemical criteria have been proposed as prognostic factors [3-7] and [8]. However, WHO classification, extent of surgical resection are the most important variable in predicting outcome $[\mathbf{8 , 9}]$.

The identification of biological correlates of outcome and therapeutic targets remains a significant challenge in this disease [8,9].

There are isoforms of the glial fibrillary acidic protein (GFAP); GFAP- $a$, GFAP- $\delta$, and etc [10]. Also they are part of the interme- 
Tena-Suck et al. Journal of Histology \& Histopathology 2015,

diate filaments $[10,11]$, each of these different isoforms are involved in different biological processes, in both protein and filament associations as well as Jnk phosphorylation [10,11]. GFAP- $\delta$ in brain tumors assembly and function remains poorly understood [10-13].

The aim of this study was to identify histological and immunohistochemical profile with a specific emphasis the PGAF- $\delta$ expression that might better correlate with clinical course in patients with ependimomas treated with surgical resection in a single Mexican institution.

\section{Materials and methods}

Sixty primary and recurrent ependimomas were retrieved from the files of pathology archives, patients that were operated from 1990 to 2009 at the National Institute of Neurology and Neurosurgery (INNN) in México City. Clinical information and follow-up data were available in all cases and were graded according to the 2007 WHO classification [1]. Clinical data analysed: Age, gender, localization and size of tumour, time of onset of symptoms, surgical exeresis, recurrence and progression free survival (PFS) and the overall survival (OS) and were recorded. Data on age at diagnosis, degree of surgical resection, further treatment, and current status were obtained to assess prognostic implications of the current grading system, of histological and immunohistochemical features.

\section{Histopathology}

Ependymomas were processed formalin-fixed paraffinembedded tumour material. Areas of viable and representative tumour following review of all blocks were marked by a pathologist prior observation. Tumor were classified according to WHO grade criteria [1].

Chronic Inflammation (presence of lymphocytes, plasma cells infiltration) rosettes and pseudorosettes formation, gross and hialinizated vessels and macrophages, necrosis, hemorrhage, pleomorphsm, atypia, mitotic index, brain infiltration and gliosis were evaluated in each case. Clinicopathological correlation was made.

\section{Immunohistochemistry}

The samples were deparaffinized in xylene, and hydrated through decreasing concentrations of ethanol. For Ki-67, PCNA Glial fibrilary acidic protein (GFAP), Glial fibrilary acidic protein delta (GFAP- $\delta$ ), Epithelial Membrane antigen (EMA) E-Cadherin and Neurofilament (NF) were used as primary antibodies (see Table 1). Antigen retrieval (Sodium citrate buffer (pH 6.0, Biocare) was used in a pressure cooker for 5 min at full pressure before primary antibody that were all incubated overnight at $4^{\circ} \mathrm{C}$.

GFAP, GFAP- $\delta$ and EMA were scored as the percentage of immunopositive cells divided by the total number evaluated,

Table 1. Clinical data and it correlation with histological grade.

\begin{tabular}{|c|c|c|c|c|}
\hline Clinical data & Grade I N=15(\%) & Grade II N=36(\%) & Grade III N=9(\%) & $P$ value \\
\hline Age & $21-65 y 34 \pm 14.43 y$ & $18-57$ y $33.50 \pm 10.59 y$ & $18-43$ y $30.22 \pm 8.43 y$ & 0.074 \\
\hline $\begin{array}{l}\text { Female } \\
\text { Males }\end{array}$ & $\begin{array}{l}11(73) \\
4(27)\end{array}$ & $\begin{array}{l}15(42) \\
21(58)\end{array}$ & $\begin{array}{l}6(67) \\
3(33 .)\end{array}$ & 0.081 \\
\hline $\begin{array}{l}\text { Tumor localization } \\
\text { Supratentorial } \\
\text { Infratentorial spinal }\end{array}$ & $\begin{array}{l}0 \\
0 \\
15(100)\end{array}$ & $\begin{array}{l}13(36) \\
22(61) \\
0\end{array}$ & $\begin{array}{l}4(44) \\
2(22) \\
3(33)\end{array}$ & $\begin{array}{l}0.000^{*} \\
0.000^{* *}\end{array}$ \\
\hline Tumor size (mm) & $36.75 \pm 6.76 \mathrm{~mm}$ & $38.13 \pm 8.54 \mathrm{~mm}$ & $47.89 \pm 5.96 \mathrm{~mm}$ & $0.019^{*}$ \\
\hline Time of onset of symptoms & $12.33 \pm 12.25 \mathrm{mo}$ & $12.25 \pm 2.20 \mathrm{mo}$ & $9.44 \pm 2.40 \mathrm{mo}$ & $0.030^{*}$ \\
\hline Recurrence & $4(28.57) \mathrm{mo}$ & 13(36.1)mo & $6(66.6) \mathrm{mo}$ & 0.136 \\
\hline Time of Recurrence & $2.07 \pm 4.51 \mathrm{mo}$ & $3.94 \pm 5.84 \mathrm{mo}$ & $7.33 \pm 5.63 \mathrm{mo}$ & $\begin{array}{l}0.066 \\
0.030^{\text {** }}\end{array}$ \\
\hline $\begin{array}{l}\text { Partial exeresis } \\
\text { Total exeresis }\end{array}$ & $\begin{array}{l}12(80) \\
3(20)\end{array}$ & $\begin{array}{l}24(66.6) \\
12(33.3)\end{array}$ & $\begin{array}{l}6(67) \\
3(33)\end{array}$ & 0.621 \\
\hline Follow-up & $29.36 \pm 10.01 \mathrm{mo}$ & $20.40 \pm 9.30 \mathrm{mo}$ & $12.22 \pm 9.23 \mathrm{mo}$ & 0.005 \\
\hline $\begin{array}{l}\text { Evolution Equal to star } \\
\text { With improvement } \\
\text { With worsening }\end{array}$ & $\begin{array}{l}2(13) \\
9(87) \\
4(27)\end{array}$ & $\begin{array}{l}1(3) \\
25(69) \\
10(28)\end{array}$ & $\begin{array}{l}3(33) \\
1(11) \\
1(11)\end{array}$ & $\begin{array}{l}0.011^{*} \\
0.062\end{array}$ \\
\hline Brain Infiltration & $1(7)$ & $9(25)$ & $9(100)$ & $\begin{array}{l}0.000^{*} \\
0.000^{* *}\end{array}$ \\
\hline Death & $4(27)$ & $5(20)$ & $6(67)$ & $\begin{array}{l}0.005^{\star} \\
0.098\end{array}$ \\
\hline
\end{tabular}

${ }^{*}$ chi square, ${ }^{* \star}$ Pearson correlation, media and standard derivation were calculated in tumor size, age, time of Time of onset of symptoms, recurrences and time of follow-up. 
including staining intensity range; 0 (none), $+($ weak $),++$ (moderate) and $+++($ strong). Only tumors with strong $(2+)$ staining in $>25 \%$ cells were considered positive.

E-cadherin protein expression was defined as membranous staining cells or lacking. And was evaluated as intensity defined as 0 , no staining observed, $1(+)$ weak staining, $2(++)$ moderate membrane staining and $3(+++)$, strong complete membrane staining in the tumour cells.

Ki-67 and PCNA labelling index (li) were estimated by counting the number of MIB-1 antibody positive cells from a total of approximately 400 cells in the most proliferative areas of the tumors. The final li was taken from the mean of five cores [13].

\section{Statistical analysis}

Statistical analyses were performed using SPSS v16.0. Univariate analysis of the association of protein expression levels with clinical variables was assessed by Fisher's exact test and Pearson and Spearman Correlations. Kaplan-Meier survival curves were constructed to investigate candidates as prognostic markers. Multivariate cox regression hazard analysis was used to identify independent prognostic markers. A $P$-value of $<0.05$ was considered statistically significantive.

\section{Results}

Sixty cases of ependymoma were included in this study. Age, gender, tumor location and clinical data of the cases are shown in Table 1. Location; 17 (28.3\%) cases were supratentorial, $25(41.6 \%)$ were in the posterior fossa and $18(30 \%)$ were spinal cord. There was recurrence in $23(38 \%)$ cases $(4(17 \%)$, $13(56 \%)$ and $6(26 \%)$ grade III respectively). Age ranged from recurrence tumor were $34.52 \pm 12.23 \mathrm{yr}$ in non-recurrence tumors were $33.97 \pm 97.94 \mathrm{yrs}$. Histopathological features and immunohistochemical results according tumor location are seen in Table 2. Cellular subtype were 9(15\%), papillar $23(38 \%)$, clear cell were $8(13 \%)$, anaplastic $7(12 \%)$, mixopapillar 9(15) and tanacytic type were $4(7 \%)$ cases (Figure 1). Immunohistochemistry results according tumor grade (WHO classification) are shown in Table 3. E-cadherin was moderate immunoreaction positive in grade I in $18(80 \%)$ and was negative grade II and Grade III (Figures 1a-1d). As well as EMA was weak positive in $8(53 \%)$ grade I, and was negative in grade II and III. GFAP $\delta$ was strong in grade III and negative in grade I vs II (Figures 1e-1h). GFAP in grade I was strong in $3(20 \%)$, grade II in $4(11 \%)$ and negative in grade III (Figures 1i-1I). However, Neurofilament was weak expression in grade I in $5(33 \%)$ and the most of them grade II and grade III were negative. Ki67-labeling index mean ranged was $2.74- \pm 704 \%$ in grade $\mathrm{I}, 4.69 \pm .980 \%$ in grade II and $8.22 \pm .980 \&$ in grade III ( $p=.000)$. Ki67-li according tumor location was $5.47 \pm 1.5 \%$ supratentorial tumors, $5.36 \pm 1.4 \%$ in posterior fossa and $5.56 \pm 1.4 \%$ in spinal cord.

There was no statistically significative relationship between expression of GFAP- $\delta$ with gender, there was higher correlation with females than in male $(p=0.012)$. Ki67 was
Table 2. Histological findings, subtypes and correlation with tumor localization.

\begin{tabular}{|c|c|c|c|c|}
\hline $\begin{array}{l}\text { Histological } \\
\text { findings }\end{array}$ & $\begin{array}{l}\text { Suprat } \\
\text {-entorial } \\
\mathrm{N}=17(\%)\end{array}$ & $\begin{array}{l}\text { Infrat } \\
\text {-entorial } \\
\mathrm{N}=25(\%)\end{array}$ & $\begin{array}{l}\text { Spinal } \\
\mathrm{N}=18(\%)\end{array}$ & P value \\
\hline \multicolumn{5}{|l|}{ Subtypes } \\
\hline Mixopapillar & 0 & 0 & $15(83)$ & \\
\hline Papillar & $6(35)$ & $10(40)$ & 0 & \\
\hline Cellular & $3(18)$ & $6(24)$ & 0 & \\
\hline Clear cells & $4(26)$ & $4(16)$ & 0 & \multirow[t]{3}{*}{$0.000^{*}$} \\
\hline Tanynytic & 0 & $2(8)$ & 0 & \\
\hline Anaplastic & $3(18)$ & $3(12)$ & $3(17)$ & \\
\hline Atypia & $8(47)$ & $13(52)$ & $3(17)$ & $0.037^{\star}$ \\
\hline Pleomorphism & $8(47)$ & $13(52)$ & $3(17)$ & $0.037^{\star}$ \\
\hline Mitosis & $6(35)$ & $7(28)$ & $3(17)$ & $0.452^{*}$ \\
\hline Necrosis & $16(94)$ & $8(32)$ & $8(44)$ & $0.000^{*}$ \\
\hline Hemorrhage & $16(94)$ & $11(44)$ & $10(56)$ & $0.004^{*}$ \\
\hline Calcification & $17(100)$ & 0 & 0 & $0.000^{*}$ \\
\hline Gross vessels & $4(24)$ & $9(36)$ & $15(83)$ & 0.000 \\
\hline Rosettes & $17(100)$ & $13(52)$ & $7(39)$ & 0.000 \\
\hline invasion & $7(41)$ & $9(36)$ & $7(39)$ & $0.943^{*}$ \\
\hline Tumor size & $36.68 \pm 8.0$ & $41.12 \pm 6.93$ & $39.44 \pm 8.7$ & 0.004 \\
\hline \multicolumn{5}{|l|}{ Neurofilaments } \\
\hline Negative & $10(59)$ & $10(40)$ & $18(100)$ & \multirow[t]{4}{*}{$0.000^{* *}$} \\
\hline Weak & $1(6)$ & $12(48)$ & 0 & \\
\hline Moderate & 0 & $2(8)$ & 0 & \\
\hline Strong & $13(76.4)$ & $1(4)$ & 0 & \\
\hline \multicolumn{5}{|l|}{ E-cadherin } \\
\hline Negative & 0 & $11(44)$ & $12(67)$ & \multirow[t]{4}{*}{0.094} \\
\hline Weak & $5(29)$ & $7(28)$ & $3(17)$ & \\
\hline Moderate & $5(29)$ & $4(16)$ & $3(17)$ & \\
\hline Strong & $7(41)$ & $3(12)$ & 0 & \\
\hline \multicolumn{5}{|l|}{ EMA } \\
\hline Negative & $3(18)$ & $14(56)$ & $15(87)$ & \multirow[t]{2}{*}{0.979} \\
\hline positive & $14(82)$ & $11(44)$ & $3(17)$ & \\
\hline \multicolumn{5}{|l|}{ GFAP } \\
\hline Weak & $9(53)$ & $11(44)$ & $9(50)$ & \multirow{3}{*}{$0.015^{\star *}$} \\
\hline Moderate & $5(29)$ & $13(52)$ & $6(33)$ & \\
\hline Strong & $3(18)$ & $1(4)$ & $3(17)$ & \\
\hline Ki-67li & $5.36 \pm 1.4$ & $5.47 \pm 1.5$ & $5.56 \pm 1.4$ & $0.013^{* *}$ \\
\hline
\end{tabular}

${ }^{\star}$ chi square, ${ }^{* \star}$ Pearson correlation, media and standard derivation were calculated in tumor size and ki67li.

higher in anaplastic type and grade III than grade I $(p=0.000)$. The size tumor $(p=0.023)$, brain invasion $(p=0.003)$, atypia $(p=0.000)$, mitosis features $(p=0.041)$, were correlated with higher neurofilament expression $(p=0.000)$, higher rates of Ki-67 Li ( $p=0.013)$.

Comparison of recurrence curves according to histological grade during the ensuing months. In the analysis, we used the log rank test for comparison of the curves of recurrence, 

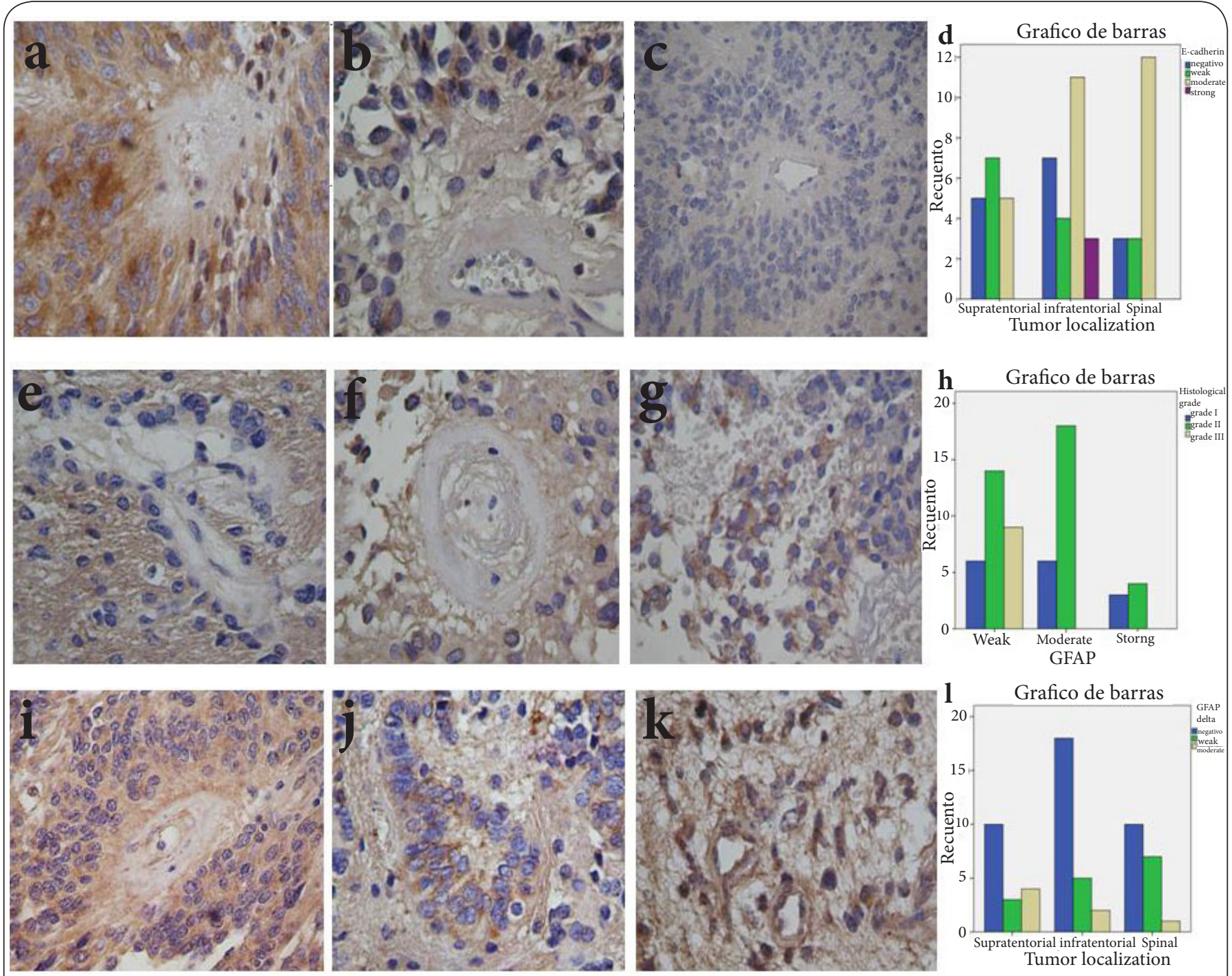

Figure 1. (a) immunohistochemistry. In (a, b and $\mathbf{c}$ ) we observed the E-cadherin immunoexpression, (a) papillary ependymoma, in (b) cellular subtype and (c) in anaplastic subtype, and in (d) we observed a histogram that showed the correlation between the E-Cadherin immunohistochemistry results and tumor grade. In the features $(\mathbf{e}, \mathbf{f}, \mathbf{g})$ we observed the immunoreaction of GFAP in papillary in e) cellular subtype in (f) and in (g) showed the positive immunoreactivity in anaplastic ependymoma. (h) Showed a histogram that showed the relationship between histological grade and GFAP immunoexpression. GFAP $\delta$ immunoexpression in (h) papillary ependymoma, (i) cellular subtype and (j) showed the positive immunoreaction in anaplastic subtype and in (l) observed the histogram of GFAP- $\delta$ immunoexpression and its relationship with histological grade.

yielding a $p$-value $<0.001$, indicating that we reject the null hypothesis that the three curves are equal, therefore we can conclude that patients with ependymomas had a different probability of recurrence according to histologic grade of the presentation during the 45 month follow-up (Figure 2a). That showed the comparison of the curves between the relapse according to level of GFAP- $\delta$ during the ensuing months. In the analysis, we used the log rank test for comparison of the curves of recurrence, yielding a $p$-value $<0.001$. Indicating that we reject the null hypothesis that the three curves are equal, therefore we can conclude that patients with ependymomas had a different probability of relapse according to level of GFAP- $\delta$ during the 45 months (Figure $2 b$ ).

In Figure 2 observed the Kaplam-Maier curves of relapse survival function and histological grades (Figur 2a), histological grades and GFAP $\delta$ immunoexpression (Figure $\mathbf{2} \mathbf{b}$ ) and level of e-cadherin positive reaction (Figure 2c). We observed that tumor grade I had better prognosis than grade III, and loss of E-cadherin in grade III.

\section{Discussion}

Clinical and biological perspective, the ependymomas of 
Tena-Suck et al. Journal of Histology \& Histopathology 2015, http://www.hoajonline.com/journals/pdf/2055-091X-2-17.pdf

Table 3. Immunohistochemical antibodies used and results.

\begin{tabular}{|c|c|c|c|c|}
\hline Antibody & $\begin{array}{l}\text { Grade I } \\
\mathrm{N}=15(\%)\end{array}$ & $\begin{array}{c}\text { Grade II } \\
\mathrm{N}=36(\%)\end{array}$ & $\begin{array}{l}\text { Grade III } \\
\mathrm{N}=9(\%)\end{array}$ & P value \\
\hline \multicolumn{5}{|l|}{ GAFP } \\
\hline weak & $6(40)$ & $14(38.8)$ & $5(55.5)$ & \multirow{3}{*}{0.612} \\
\hline moderate & $6(40)$ & $18(50)$ & $4(44.4)$ & \\
\hline strong & $3(20)$ & $4(11.1)$ & 0 & \\
\hline \multicolumn{5}{|l|}{ GAFP- $\delta$} \\
\hline negative & $10(66.6)$ & $22(61.1)$ & 0 & \multirow{4}{*}{0.000} \\
\hline weak & $5(33.3)$ & $10(27.7)$ & 0 & \\
\hline moderate & $5(33.3)$ & $4(11.1)$ & $3(33.3)$ & \\
\hline strong & 0 & 0 & $6(66.6)$ & \\
\hline \multicolumn{5}{|c|}{ E-Cadherin } \\
\hline negative & 0 & $6(16.6)$ & $9(100)$ & \multirow{4}{*}{0.000} \\
\hline weak & $3(20)$ & $12(33.3)$ & 0 & \\
\hline moderate & $12(80)$ & $16(44.4)$ & 0 & \\
\hline strong & 0 & $3(8.3)$ & 0 & \\
\hline \multicolumn{5}{|l|}{ EMA } \\
\hline negative & $(46.6)$ & $17(47.2)$ & $9(100)$ & \multirow[t]{2}{*}{0.013} \\
\hline weak & $8(53.3)$ & $19(52.7)$ & 0 & \\
\hline \multicolumn{5}{|c|}{ Neurofilaments } \\
\hline negative & $10(66.6)$ & $21(58.3)$ & 0 & \multirow[t]{4}{*}{0.000} \\
\hline Weak & $5(33.3)$ & $12(33.3)$ & $2(22.2)$ & \\
\hline Moderate & 0 & $3(8.3)$ & $5(55.5)$ & \\
\hline Strong & 0 & 0 & 1(11.1) & \\
\hline Ki67-li & $2.74- \pm 704$ & $4.69 \pm .980$ & $8.22 \pm .980$ & 0.000 \\
\hline
\end{tabular}

${ }^{*}$ chi square, ${ }^{* *}$ Pearson correlation. Media and standard derivation was calculated in ki-67li.

childhood and in adults remain enigmatic about the treatment [8-10]. There are good prognostic factors, that including; age of the patient, tumors location, surgical resection $[5,6]$. The most widely accepted prognostic factor is the degree of surgical resection, a complete resection is always associated with a good prognosis [1]. A complete tumour resection is an independent prognostic marker, indicating a better patient outcome [8-10]. Ependymomas in children's are more aggressiveness than adults and develop metastases, a higher recurrence rate and tumour dissemination than adult [8-10]. Few articles have been published about the genes and genetic mechanisms underlying patients relapse and survival and tumorigenesis. Chromosome 1q gain is the most common genetic change in ependymoma [14], and are involved in the kinetochore (ASPM, KIF11) or in neural development (CD133, Wnt and Notch pathways). Metallothionein (MT) genes has been detected down regulated in up to $80 \%$ of the recurrences [14].

The relationship between outcome and histological grading according to $\mathrm{WHO}$ criteria remains a controversial prognostic factor [1], some studies have found that anaplasia carries a poorer prognosis, whereas others have not [3-5]. Histological and molecular differences between grade II and grade III ependymoma requires variety of pathological features $[4,5]$. A several studies of "biological" markers have been identified to be of prior prognostic significance, that including the Ki-67 labelling index, surviving tyrosine kinase receptor I (RTK-I) family, and telomerase (hTERT) expression $[15,16]$. he proliferation marker of Ki- 67 has been widely reported as a predictor of outcome in ependymoma, as well as in other tumor buy few studies have been conducted in adults cases [14-16].

Co-expression of ERBB2 and ERBB4, higher Ki-67 labelling index (LI), and degree of surgical resection have been reported to be predictive of poor prognosis in ependymoma [17]. We have shown that higher Ki67-li correlated with WHO grade III, in concordance with a previous study in a cohort of adult ependymoma [1], with grade predicting outcome [14-16]. This supports evidence that higher proliferative activity is one of many features associated with pleomorphism, and atypia with grade III ependymoma [1-4]. However, neither grade nor Ki67-li predicted outcome, highlighting that the prognostic significance of grade in paediatric ependymoma remains controversial [14-16].

Immunohistochemical results found seen to be important in the differential diagnosis of ependymoma from other no ependymal tumors and in differentiating between the various grades of ependymoma [1]. So far, the glial fibrillary acidic protein (GFAP) and vimentin are used for distinguishing ependymoma from other brain tumors [1]. Nevertheless, a panel of antibodies is usually required for an accurate final diagnosis. So far, GFAP and vimentin are 2 markers that are used for distinguishing ependymomas from other tumors of the CNS, especially choroid plexus tumors and astrocytic tumors [1]. S-100 protein and GFAP staining is seen in all ependymomas, particularly in true and perivascular pseudo rosettes [1]. Myxopapillary ependymomas can be positive for Cytokeratins (CAM 5.2, AE1 AE3, CK7) but are usually negative for CK20 and focally for EMA, and co-expression of GFAP, s-100 protein which could be misdiagnosed as metastatic carcinoma $[1,17]$. The planned histogenesis of extramedullary MPE in this location is the presence of ependymal rest of the neural tube during canalization and retrogressive differentiation [1]. CD99 can later be suggested for use as a good marker for difference between ependymal tumors between other CNS tumours [18]. S-100 protein reactivity has been observed, in association with the resection status and tumour location are the only indicators of prognosis, with complete resection and supratentorial tumours demonstrating a better patient outcome [1].

EMA expression and pattern of distribution, on the other hand, cannot be employed to determine the type of variant or the degree of tumour aggressiveness $[1,19]$. EMA could not differentiate between different grades of ependymoma. EMA reactivity is largely limited to luminal staining of rosettes and tubules [19].

GFAP- $\delta$ is an isoform that differs in its C-terminal sequence from other GFAP isoforms and suggested restriction of as- 
Tena-Suck et al. Journal of Histology \& Histopathology 2015,

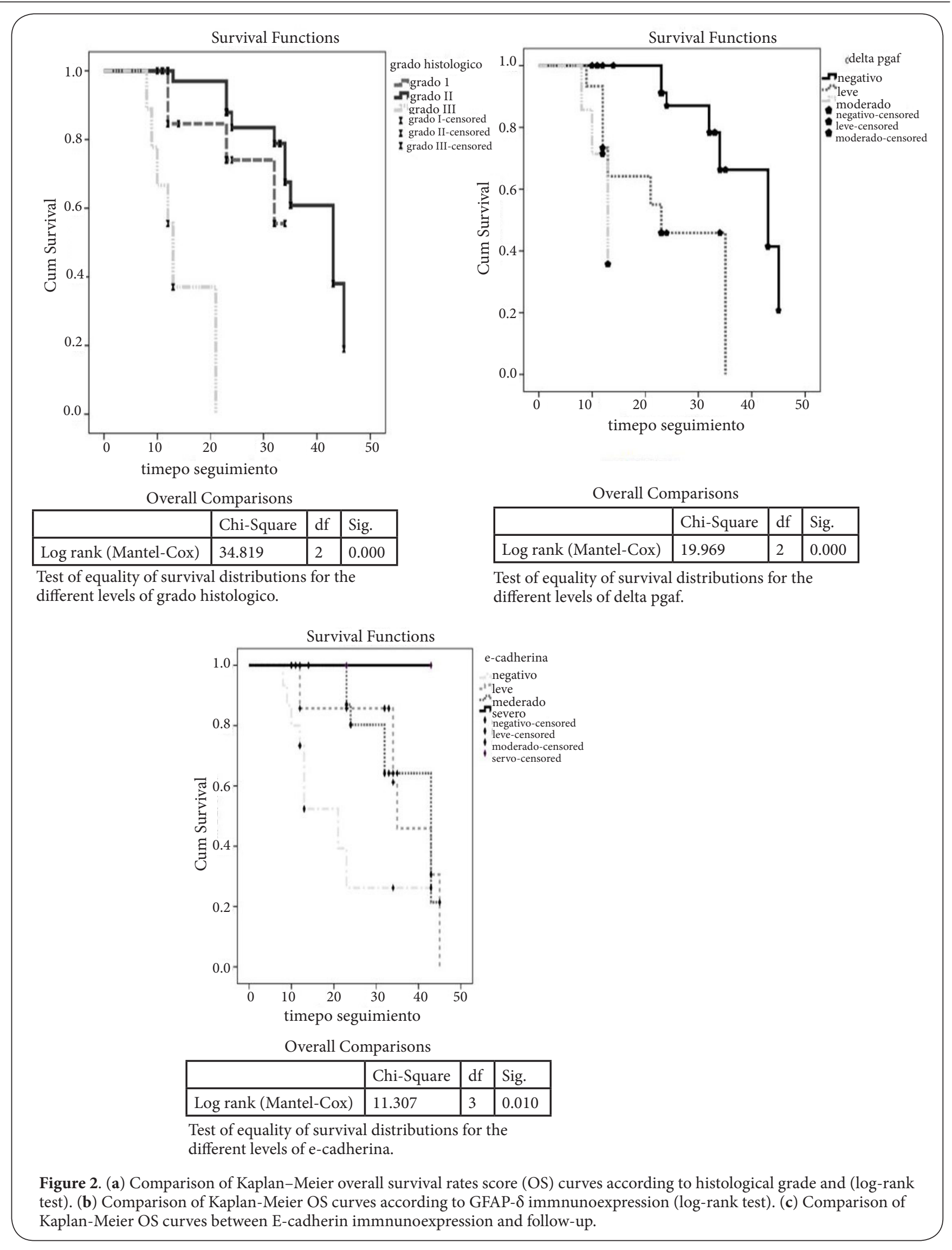


trocytes expression to the subpial layer, subventricular zone and the subgranular zone, in pathological conditions and reactive gliosis $[10,11]$. GFAP- $\delta$ is speculated to have roles in regulation of astrocyte size and motility and a subpopulation of GFAP- $\delta$-positive glia may be multipotent stem cells [11]. The presence of GFAP- $\delta$ changes the assembly and filamentfilament interactions of the GFAP filament. The tail domain of GFAP- $\delta$ could mediate specific interactions with a subset of cytoplasmic partners, such as presenilin [11]. These mechanisms can also lead to increased filament-filament associations and aggregate formation, but this is usually in the context of disease for GFAP and GFAP- $\delta$ highlight an emerging pattern for the assembly of type III IFs in terms of the incorporation of other filament subunits to modulate IF function. For instance, nestin like GFAP- $\delta$ have been assembly-compromised in vitro, the distribution of the mutations throughout the GFAP sequence, and possible genotype/phenotype correlations in immature astrocytes $[\mathbf{1 1}, \mathbf{1 2}, \mathbf{1 9}, \mathbf{2 0}]$. The positive reaction to GFAP- $\delta$ and nestin have been reported that reactivity is higher in highly invasive tumors compared with low-invasive tumors [19]. Altogether, these results suggest that GFAP- $\delta$ and nestin could be clinically relevant markers associated with tumor invasiveness in cerebral astrocytomas as well as, with ependymomas.

Heo $\mathrm{DH}$, et al [12]. Observed that the optical density of GFAP- $\delta$ increased significantly with astrocytoma grade and suggest that GFAP- $\delta$ may be an additional, reliable histopathological diagnostic marker for spinal cord astrocytomas. Furthermore, the malignancy of astrocytic tumor was directly correlated with the degree of GFAP-delta immunoreactivity [11]. These findings suggest that GFAP-delta as well as nestin may be a useful diagnostic marker for the evaluation of functional anaplastic or proliferation of astrocytic tumour [11]. According to the theory of glioma oncogenes, the transformation of a cell population with stem features which resides in the SVZ could be the origin of astrocytomas as well as ependymomas. Moreover, it is known that cancer stem cells promote tumor invasion in cerebral astrocytomas [19]. GFAP- $\delta$ and nestin could be clinically relevant markers with a useful diagnostic marker for the evaluation of functional atypia or proliferation of astrocytic tumor [20].

In this work the authors observed that the expression of GFAP- $\delta$ might be related to a high index of ki67-li, with histologic grade, E-cadherin loss expression and neurofilament expression.

E- Cadherin has been demonstrated to be essential components of the adherens junction complexes that mediate cell-cell adhesion and regulate cell motility. During tissue morphogenesis, changes in cadherin expression (known as cadherin switching) are a common mechanism for altering cell fate $[18,21]$.

Cadherin switching is also common during epithelial tumour progression, where it is thought to promote tumour invasion and metastasis [22,23]. E-cadherin is the predominant cadherin expressed in epithelial tissues, but its expression is very limited in normal brain [22].

The losses of expression of E-cadherin as well as EMA immnunoexpression have been observed in several tumor types and especially in malignant tumors. 12 We observed that the loss of expression of E-cadherin was directly related to the abnormal isoform expression of GFAP as well as the expression of neurofilament [22].

The brain tumour stem cells express neural precursor markers, suggesting that they may be derived from normal neural precursors that they are capable of differentiation, and aberrant expressions [24]. The fact that any differentiation is possible suggests that brain tumour cells retain some aspects of a functional developmental programme, demanding further research into understanding the role of developmental signalling pathways in brain tumours $[25,26]$. Those tumour markers with neural progenitor-like features have been observed in medulloblastoma and ependymomas in children [3]. Ependymomas are tumours thought to derive from radial glial cells and display morphological characteristics of normal ependymal [1]. Advances have been made in our understanding of the molecular mechanisms underlying the oncogenesis of ependymoma with the discovery of specific cancer stem cells and the definition of gene expression profiles specific of each location [25].

Brain tumour stem cells have potent. Tumour-initiating and maintaining ability, a property not shared by most of the cells in the tumour. Moreover, human ependymoma cells had gene expression profiles that resembled that of normal radial glial cells (putative NSCs) isolated from the same relative rostral-caudal position in the neuraxis as where the tumour was found [26]. Other studies have been suggested that human ependymomas arise from regionally distinct populations of radial glial cells $[\mathbf{2 4 , 2 6 ]}$, with abnormal GFAP- $\delta$ positive expression [15]. GFAP- $\delta$ increased significantly with tumor grade [27].

\section{Conclusion}

In this study, we observed that the expression of GFAP- $\delta$ could be related with a higher Ki-67 and PCNA Li, high histological grade, presence of neurofilament and loss of E-cadherin and EMA immuno expression.

\section{Competing interests}

The authors declare that they have no competing interests.

\section{Authors' contributions}

\begin{tabular}{|l|c|c|c|c|}
\hline Authors' contributions & MLTS & MCL & ADA & CSG \\
\hline Research concept and design & $\checkmark$ & $\checkmark$ & $\checkmark$ & $\checkmark$ \\
\hline Collection and/or assembly of data & $\checkmark$ & $\checkmark$ & $\checkmark$ & $\checkmark$ \\
\hline Data analysis and interpretation & $\checkmark$ & $\checkmark$ & $\checkmark$ & $\checkmark$ \\
\hline Writing the article & $\checkmark$ & $\checkmark$ & $\checkmark$ & $\checkmark$ \\
\hline Critical revision of the article & $\checkmark$ & $\checkmark$ & $\checkmark$ & $\checkmark$ \\
\hline Final approval of article & $\checkmark$ & $\checkmark$ & $\checkmark$ & $\checkmark$ \\
\hline Statistical analysis & $\checkmark$ & $\checkmark$ & $\checkmark$ & $\checkmark$ \\
\hline
\end{tabular}


Tena-Suck et al. Journal of Histology \& Histopathology 2015,

\section{Publication history}

Editors: Lingyan Wang, Oregon Health \& Science University, Portland.

Paola Castrogiovanni, University of Catania, Italy.

Received: 16-Apr-2015 Final Revised: 09-Jun-2015

Accepted: 30-Jun-2015 Published: 30-Jul-2015

\section{References}

1. McClendon RE, Wiestler OD and Kros JM et al. Ependymoma. World Health Organization Classification of Tumours. In: Louis DN, Ohgaki H, Wiestler OD, Cavenee WK, Editors. WHO Classification of Tumors of the Central Tumors of the Nervous System. 4. Lyon, France: IARC Press. 2007; 74-78.

2. Shuangshoti S, Rushing EJ, Mena H, Olsen $\mathrm{C}$ and Sandberg GD. Supratentorial extraventricular ependymal neoplasms: a clinicopathologic study of 32 patients. Cancer. 2005; 103:2598-605. | Article | PubMed

3. Moynihan TJ. Ependymal tumors. Curr Treat Options Oncol. 2003; 4:51723. | Article | PubMed

4. Figarella-Branger D, Civatte M, Bouvier-Labit C, Gouvernet J, Gambarelli D, Gentet JC, Lena G, Choux M and Pellissier JF. Prognostic factors in intracranial ependymomas in children. J Neurosurg. 2000; 93:605-13. | Article | PubMed

5. Zamecnik J, Snuderl M, Eckschlager T, Chanova M, Hladikova M, Tichy M and Kodet R. Pediatric intracranial ependymomas: prognostic relevance of histological, immunohistochemical, and flow cytometric factors. Mod Pathol. 2003; 16:980-91. | Article | PubMed

6. Korshunov A, Golanov A, Sycheva R and Timirgaz V. The histologic grade is a main prognostic factor for patients with intracranial ependymomas treated in the microneurosurgical era: an analysis of 258 patients. Cancer. 2004; 100:1230-7. | Article | PubMed

7. Modena P, Lualdi E, Facchinetti F, Veltman J, Reid JF, Minardi S, Janssen I, Giangaspero F, Forni M, Finocchiaro G, Genitori L, Giordano F, Riccardi $R$, Schoenmakers EF, Massimino M and Sozzi G. Identification of tumor-specific molecular signatures in intracranial ependymoma and association with clinical characteristics. J Clin Oncol. 2006; 24:5223-33. I Article | PubMed

8. Palma L, Celli P, Mariottini A, Zalaffi A and Schettini G. The importance of surgery in supratentorial ependymomas. Long-term survival in a series of 23 cases. Childs Nerv Syst. 2000; 16:170-5. | Article | PubMed

9. Bouffet $E$, Perilongo $G$, Canete $A$ and Massimino M. Intracranial ependymomas in children: a critical review of prognostic factors and a plea for cooperation. Med Pediatr Oncol. 1998; 30:319-29; discussion 329-31. | Article | PubMed

10. van den Berge SA, Middeldorp J, Zhang CE, Curtis MA, Leonard BW, Mastroeni D, Voorn P, van de Berg WD, Huitinga I and Hol EM. Longterm quiescent cells in the aged human subventricular neurogenic system specifically express GFAP-delta. Aging Cell. 2010; 9:313-26. | Article | PubMed

11. Choi KC, Kwak SE, Kim JE, Sheen SH and Kang TC. Enhanced glial fibrillary acidic protein-delta expression in human astrocytic tumor. Neurosci Lett. 2009; 463:182-7. | Article | PubMed

12. Heo DH, Kim SH, Yang KM, Cho YJ, Kim KN, Yoon DH and Kang TC. A histopathological diagnostic marker for human spinal astrocytoma: expression of glial fibrillary acidic protein-delta. J Neurooncol. 2012; 108:45-52. | Article | PubMed

13. Prayson RA. Clinicopathologic study of 61 patients with ependymoma including MIB-1 immunohistochemistry. Ann Diagn Pathol. 1999; 3:11-8. | Article | PubMed

14. Dyer S, Prebble E, Davison V, Davies P, Ramani P, Ellison D and Grundy R. Genomic imbalances in pediatric intracranial ependymomas define clinically relevant groups. Am J Pathol. 2002; 161:2133-41. | Article | PubMed Abstract | PubMed Full Text

15. Wolfsberger S, Fischer I, Hoftberger R, Birner P, Slavc I, Dieckmann $\mathrm{K}$, Czech T, Budka $\mathrm{H}$ and Hainfellner J. Ki-67 immunolabeling index is an accurate predictor of outcome in patients with intracranial ependymoma. Am J Surg Pathol. 2004; 28:914-20. I Article I PubMed

16. Gilbertson RJ, Bentley L, Hernan R, Junttila TT, Frank AJ, Haapasalo $\mathrm{H}$, Connelly M, Wetmore C, Curran T, Elenius K and Ellison DW. ERBB receptor signaling promotes ependymoma cell proliferation and represents a potential novel therapeutic target for this disease. Clin Cancer Res. 2002; 8:3054-64. | Article | PubMed

17. Vege KD, Giannini $C$ and Scheithauer BW. The immunophenotype of ependymomas. Appl Immunohistochem Mol Morphol. 2000; 8:25-31. I Article | PubMed

18. Choi YL, Chi JG and Suh YL. CD99 immunoreactivity in ependymoma. Appl Immunohistochem Mol Morphol. 2001; 9:125-9. | Article | PubMed

19. Brehar FM, Arsene D, Brinduse LA and Gorgan MR. Immunohistochemical analysis of GFAP-delta and nestin in cerebral astrocytomas. Brain Tumor Pathol. 2015; 32:90-8. | Article I PubMed

20. Choi KC, Kwak SE, Kim JE, Sheen SH and Kang TC. Enhanced glial fibrillary acidic protein-delta expression in human astrocytic tumor. Neurosci Lett. 2009; 463:182-7. | Article | PubMed

21. Hasselblatt $M$ and Paulus W. Sensitivity and specificity of epithelial membrane antigen staining patterns in ependymomas. Acta Neuropathol. 2003; 106:385-8. | Article | PubMed

22. Gumbiner BM. Regulation of cadherin-mediated adhesion in morphogenesis. Nat Rev Mol Cell Biol. 2005; 6:622-34. | Article | PubMed

23. Gumbiner BM. Regulation of cadherin adhesive activity. J Cell Biol. 2000; 148:399-404. | Article | PubMed Abstract | PubMed Full Text

24. Taylor MD, Poppleton H, Fuller C, Su X, Liu Y, Jensen P, Magdaleno S, Dalton J, Calabrese C, Board J, Macdonald T, Rutka J, Guha A,G ajjar A, Curran T and Gilbertson RJ. Radial glia cells are candidate stem cells of ependymoma. Cancer Cell. 2005; 8:323-35. | Article | PubMed

25. Chanas-Sacre G, Rogister B, Moonen G and Leprince P. Radial glia phenotype: origin, regulation, and transdifferentiation. J Neurosci Res. 2000; 61:357-63. | Article | PubMed

26. Ignatova TN, Kukekov VG, Laywell ED, Suslov ON, Vrionis FD and Steindler DA. Human cortical glial tumors contain neural stem-like cells expressing astroglial and neuronal markers in vitro. Glia. 2002; 39:193206. | Article | PubMed

27. Heo DH, Kim SH, Yang KM, Cho YJ, Kim KN, Yoon DH and Kang TC. A histopathological diagnostic marker for human spinal astrocytoma: expression of glial fibrillary acidic protein-delta. J Neurooncol. 2012; 108:45-52. | Article | PubMed

\section{Citation:}

Tena-Suck ML, Castillejos-López M, Díaz-Alba A and Sanchez-Garibay C. Expression of glial acidic fibrillary protein delta and E-cadherin in ependymomas; clinicpathological and immunohistochemistry correlation. $J$ Histol Histopathol. 2015; 2:17.

http://dx.doi.org/10.7243/2055-091X-2-17 